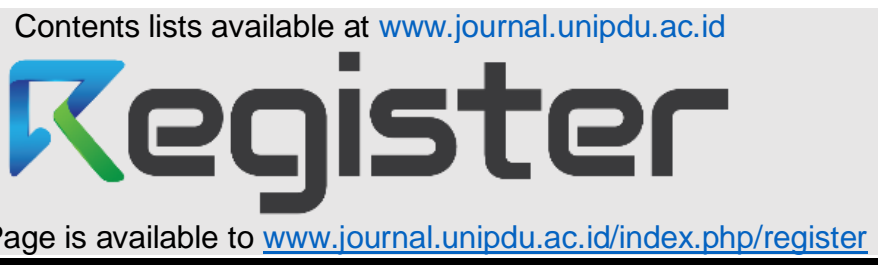

Research article

\title{
E-commerce website service quality and customer loyalty using WebQual 4.0 with importance performances analysis, and structural equation model: An empirical study in Shopee
}

\author{
I Gusti Ngurah Satria Wijaya a,", Evi Triandini ${ }^{\circ}$,Ezra Tifanie Gabriela Kabnani c, Syamsul \\ Arifin ${ }^{d}$ \\ a Department of Digital Business, Institut Teknologi dan Bisnis STIKOM Bali, Denpasar, Indonesia \\ b,c Department of Information Systems, Institut Teknologi dan Bisnis STIKOM Bali, Denpasar, Indonesia \\ ${ }^{d}$ Technology Management, Economics, and Policy Program (TEMEP), Seoul National University, Seoul, South Korea \\ email: a," ngurah_satria@stikom-bali.ac.id, bevi@stikom-bali.ac.id, c180030695@stikom-bali.ac.id, dsyamsul.arifin@snu.ac.kr
} ${ }^{*}$ Correspondence

\begin{tabular}{l} 
A R T I C L E I N F O \\
\hline Article history: \\
Received 25 January 2021 \\
Revised 2 March 2021 \\
Accepted 9 April 2021 \\
Available online 27 April 2021 \\
\hline Keywords: \\
customer loyalty \\
e-commerce \\
importance performance analysis \\
structural equation model \\
WebQual
\end{tabular}

Please cite this article in IEEE style as: I. G. N. S. Wijaya, E. Triandini, E. T. G. Kabnani and S. Arifin, " E-commerce website service quality and customer loyalty using WebQual 4.0 with importance performances analysis, and structural equation model: An empirical study in Shopee," Register: Jurnal Ilmiah Teknologi Sistem Informasi, vol. 7, no. 2, pp. 107-124, 2021

\begin{abstract}
A B S T R A C T
The rapid growth of business models in the form of online shops, Business to Consumer (B2C) and the Consumer to Consumer (C2C) concept, has an impact in the form of intense competition between online business owners. It is not easy to find a solution to this problem. The owner must provide good or even excellent service by improving the website quality so that customers can achieve satisfaction and loyalty. This research aimed to specify the influence of website quality on customer loyalty with satisfaction as an ecommerce website moderation variable and to investigate the WebQual 4.0 attributes that affect this relationship of the model. This study used 104 respondents of Shopee Consumer and analyzed with the WebQual with Importance Performance Analysis (IPA) method and Structural Equation Model (SEM). The result is that the service quality variable significantly influence e-commerce website customer satisfaction variable, customer satisfaction variable has no significant effect on e-commerce website customer loyalty variables, and website service quality variable significantly influence e-commerce website customer loyalty variable. The attributes of WebQual 4.0 that need to be considered by e-commerce management to impact the level of user satisfaction and customer loyalty are "design by the type of website", "provide simple-to-understand information", "provide information following the format", "feel safe to complete transactions", "the website makes the positive/absolute experience for $\mathrm{me}^{\prime \prime}$, and "provide detailed information". The research implications can be taken into consideration for e-commerce management.

Register with CC BY NC SA license. Copyright $\odot 2021$, the author(s)
\end{abstract}

\section{Introduction}

The impact of intense competition among online business owners is due to the rapid growth of business models in the form of online stores such as the Consumer to Consumer $(\mathrm{C} 2 \mathrm{C})$ concept, the Business to Consumer (B2C) concept, and through social media, namely Instagram, and Facebook [1, 2]. To create a sense of trust and customer satisfaction in order to survive in this business competition, customer wants and needs must be observed, studied, analyzed by the owner. [3]. It is difficult to get the answer to this problem. Excellent and good service by improving the quality of the website must be provided by the owner because it is the main liaison medium between the owner and the customer so that customers can achieve satisfaction [3]. 
Several methods have been used to test the website quality assessment, one of them is the technology acceptance model (TAM) method. Liao et al. [4] used the application of TAM to examine students' behavioral intentions in technology colleges and use a web-based accomplishment appraisal system as an instrument to assess their engineering abilities in producing electronic book. Another method used by Jebraeily et al. [5] is SERVQUAL. SERVQUAL uses five dimensions (tangibles, reliability, responsiveness, assurance, and empathy) to evaluate the hospital information system. Then analyzed the gap among user perceptions and expectations and the score significance. The last and updated method used by Andry et al. [6] is WebQual 4.0 and Importance Performance Analysis (IPA). WebQual is a method or technique of quantifying a website's quality based on the last user's perceptions. This method is an extension of SERVQUAL that was previously widely utilized in quantifying service quality. IPA is a technic that supplies two dimensions of the performanceimportance network, where importance and performance values wade the various attributes reside are plotted over each other. The resulting interest performance chamber is generally separated into four quadrants. Using WebQual 4.0 for this research, it is found that the results of the three-dimension have significant results. Customers are satisfied with certain aspects of the facilities, menu, and content of the website. Different results were obtained by Christianto et al. [7]. Christianto et al. [7] conducted tests to quantify news website's user quality and satisfaction using WebQual 4.0 dan IPA method. Results obtained that the difference between performance and importance shows a negative value, so it can be concluded that that the website's accomplishment has not fulfilled its user expectations on every study indicator.

The aim of the present study by Giao et al. [8] is to verify the effect of website quality on consumer's e-loyalty, writing down the mediating role of electronic trust, electronic satisfaction, and perceived enjoyment. Next, this research verifies the effect of consumer electronics loyalty. The outcome of this research states that website quality has a positive relationship with e-loyalty, which is partially intervened via e-trust and e-satisfaction. Also, e-loyalty and electronic word-of-mouth (e-WOM) have a positive effect. The primary results of this study suggest some of the empirical implications for Internet marketers and online sellers in Vietnam. E-vendors need to know customer expectations and e-loyalty associated with online shopping to gain new customer interest and to look at existing customers. Zhou et al. [9] conducted a research to create a metering scale for e-Service Quality (e-SQ) in telecom adjustments, and to inspect the effect among the three variables, namely e-SQ, customer satisfaction, and customer loyalty. The analysis emphasizes the positive influence among three variables, namely e$\mathrm{SQ}$, satisfaction, and loyalty. Moreover, e-SQ is known to be the main forecaster of customer satisfaction and loyalty. In addition, satisfaction came out as the dominant predictor of loyalty. Study by Huang et al. [10] explores the role of service quality and brand awareness impacting customer satisfaction and loyalty in the B2B technology service company. The study results showed that service quality has a directly proportional relationship to customer satisfaction, customer satisfaction is directly proportional to customer loyalty, and brand awareness has a directly proportional relationship to the connection between service quality and satisfaction. Raza et al. [11] in their study, aimed to examine the structural mix between the quality of Internet banking services with extended SERVQUAL dimensions, satisfaction, and loyalty with its own constructs. The results showed that the relationship between the three constructs had a positive and significant effect. Different results obtained by Mardatill et al. [12] state that the five dimensions of service quality (ease of use, web design, responsiveness, personalization, assurance) do not affect customer satisfaction. Sørum et al. [13] in their research, analyzed data on 296 websites that participated in the Danish web award, stated that website quality has no positive relationship with satisfaction.

As explained in the background and there are differences in research methods and research gap on variables that affected customer loyalty, we conduct a research with Shopee e-commerce as the object. This study's purpose is to check the impact of website quality of service on the customer's loyalty with satisfaction as a moderating variable of the e-commerce website and to investigate the WebQual 4.0 attributes that affect this relationship of the model. The last purpose of this research is to describe new things from research based on several previous studies that were referred. This research's contribution or benefit is to provide solutions for e-commerce management in managing their website regarding the attributes that are considered in supporting the quality of a system for customer 
satisfaction, so that eventually the purpose of the enterprise can be reached. This research's subjects are students of the ITB STIKOM Bali especially the study program of Information System.

\section{Related Work}

According to Jundillah et al. [14] website quality is a technique of quantifying the website quality based on the last user's perceptions. This method is a development from the SERVQUAL method used to measure service quality [15]. Haryanti and Setyorini [15] stated that WebQual is the basic concept of Quality Function Deployment (QFD), a structured process that supplies the means to recognize and convey the customer opinion via each level of production result establishment and enforcement. WebQual has been used and expanded since 1998 and has undergone several iterations to refine its dimensions and variables. The development of WebQual started from WebQual 1.0 and finally became WebQual 4.0 [16]. According to the measurement model of website quality is based on 3 attributes of WebQual 4.0, namely Usability, Information Quality, and Service Interaction [17] with 22 indicators.

IPA has the main function of providing and displaying information related to service factors that significantly influence customer satisfaction. Service factors are the attributes that need to be improved and better according to consumers since the current condition is unsatisfactory[18]. IPA intends to quantify the relationship between perceptions and consumer expectations and prioritize correcting the quality of the product or service, which is usually known as quadrant analysis [19]. This method displays a scatter diagram from the Importance-Performance Analysis by having the criteria contained in 4 quadrants. For the quadrants, see Fig. 1.

High Importance

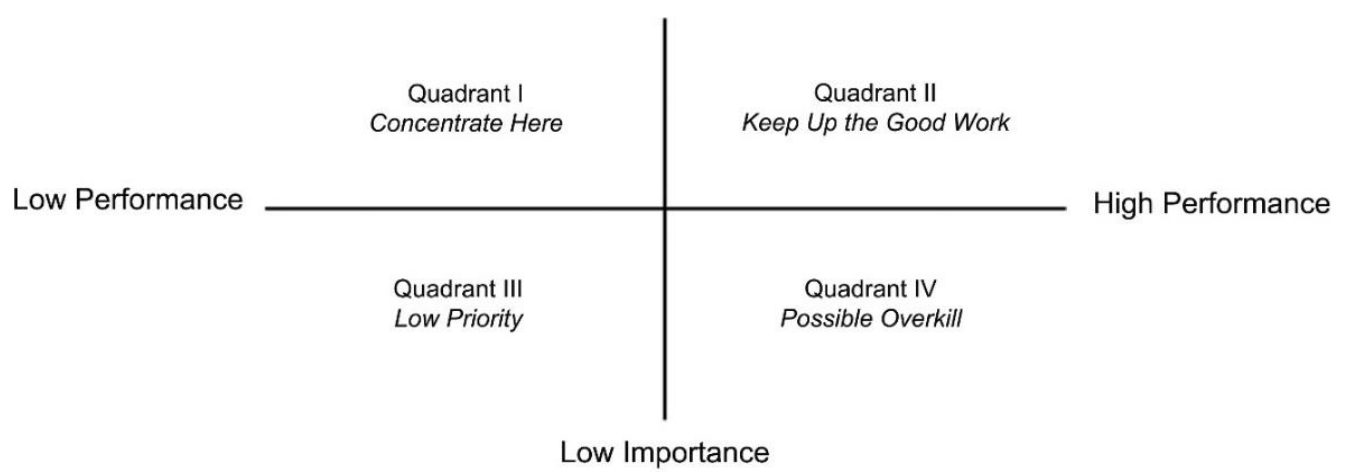

Fig. 1. Importance Performance Analysis (IPA) model [6]

Satisfaction is an expression that is expressed whether it is happy or not, compared between the expectations of a product (expected) and the reality of the product (obtained) [20]. Satisfaction is a consumer's response to fulfilling their needs. Customer satisfaction includes the difference between expectations and the performance or results felt by the customer. Customer Satisfaction consists of three main aspects. First, General Satisfaction, a situation where the customer is satisfied with the overall benefits of the product or service. Second, Confirmation of Expectations, a situation where there is a level of conformity between the performance that has been received and the expected expectations. The last, Ideal Situation, a condition where the performance of the product or service used is compared to similar products, which are ideal according to consumers [21].

According to Kotler \& Armstrong [22], maintaining customer loyalty is something that makes sense in our minds economically. Loyal customers usually use the company's products more than regular customers and for a longer period of time. Losing a loyal customer can mean losing the revenue stream from that customer in the future. There are three characteristics of loyal customers. The first characteristic is Repeat Purchases, defined as the availability and ability of customers to buy or reuse products or services in the future. Second is Referral, which means the willingness and desire of customers to refer and provide directions or recommendations to buy products or services to friends or other people. The last is Retention, a situation or condition where the buyer feels bound and obliged to use the brand, which causes the consumer to choose and buy the product again, even though there are many substitute products available on the market.

\section{Method}

Quantitative descriptive is used in this study. Descriptive research aims to provide an overview of a social/natural phenomena systematically, factual, and actual manner. This research wants to do 
scientific research systematically by providing facts and research results in the form of data of calculated numbers [23]. This research consists of several stages for collecting research materials and research analysis (WebQual 4.0 with IPA and structural equation model) as shown in Fig. 2.

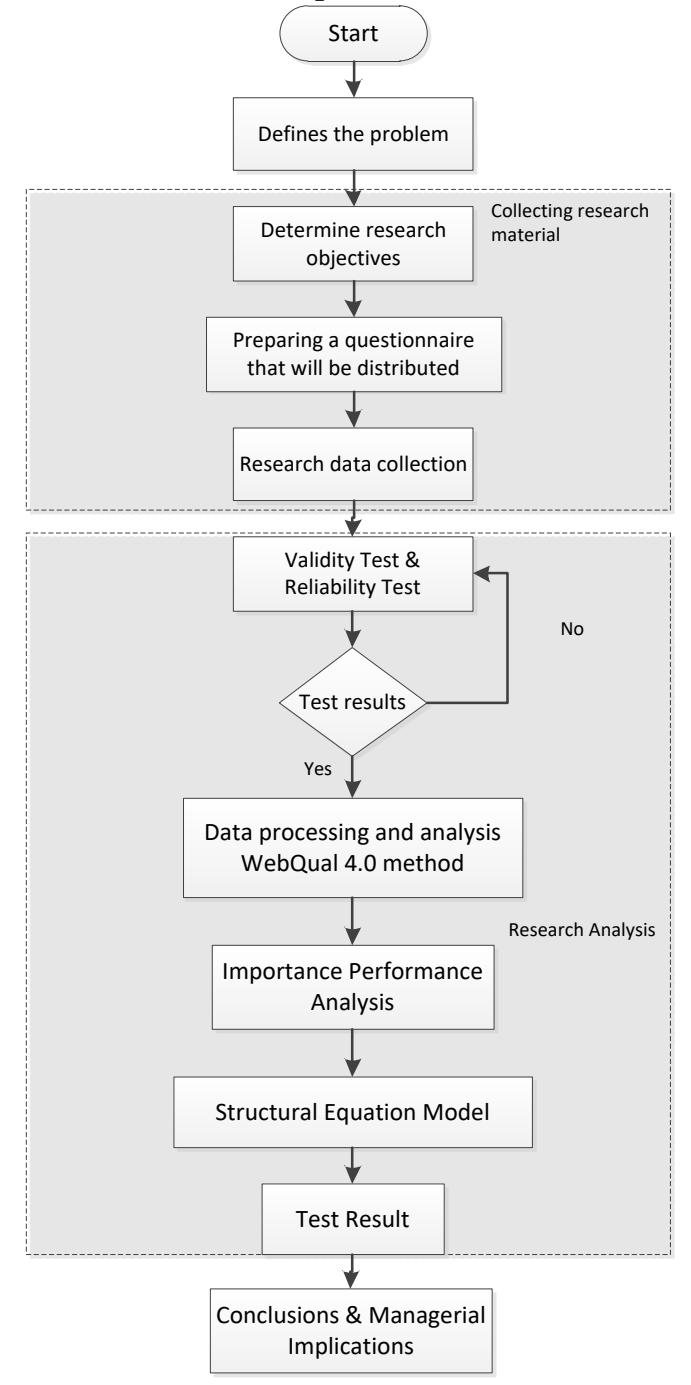

Fig. 2. Research flow

\subsection{Questionnaire}

In this study, the primary data collection technique is used by creating and distributing questionnaires. Questionnaires are created using the help of Google Form and the links are distributed to research objects or respondents, namely students. These students are students of Information System study program, ITB STIKOM Bali. The selection of respondents from these students is based on the consideration that these students are generation $\mathrm{Z}$ from the Industrial Revolution 4.0 era and understand the development of digital technology advances, especially in the field of information systems. So that, generally, they are used to making online purchase transactions. A total of 104 respondents were selected and used as respondents.

\subsection{Data collection techniques}

The purposive sampling method was selected and used to determine and select respondents. This sampling technique is the determination of the sample with specific considerations [24]. The terms used are as follows:

a. ITB STIKOM Bali students aged 17 years and over.

b. Have a login for the Shopee.co.id website.

c. Have made a purchase transaction at Shopee.

\subsection{Measurement of research variables}

This study used the WebQual 4.0 analysis to observe the quality of a website, an approach that is reused from previous studies while using another different research object, which is Shopee. This method has 
3 dimensions and 22 attributes of quality measurement service sites [25]. These indicators can be found in Table 1.

Table 1. Attributes WebQual 4.0

\begin{tabular}{|c|c|}
\hline Dimension & Indicator \\
\hline Usability & $\begin{array}{l}\text { Ease of operating the website (US1) } \\
\text { Interaction with the website is easy to understand (US2) } \\
\text { Ease of navigating the website (US3) } \\
\text { Convenient of use of the website (US4) } \\
\text { The website has an interesting look (US5) } \\
\text { Type of website based on its design (US6) } \\
\text { The website is convincing and competent (US7) } \\
\text { The website makes a positive or absolute experience (US8) }\end{array}$ \\
\hline Information Quality & $\begin{array}{l}\text { Provide proper information (IQ1) } \\
\text { Provide reliable output or information (IQ2) } \\
\text { Provide timely information (IQ3) } \\
\text { Provide relevant information (IQ4) } \\
\text { Provide information that is simple to realize (IQ5) } \\
\text { Provide detailed information (IQ6) } \\
\text { Provide information according to format (IQ7) }\end{array}$ \\
\hline Service Interaction & $\begin{array}{l}\text { Have a good reputation (SI1) } \\
\text { Feel safe and protected to carry out transactions (SI2) } \\
\text { Feel safe providing personal information (SI3) } \\
\text { Can guarantee the safekeeping of personal information (SI4) } \\
\text { Have a good image in the community (SI5) } \\
\text { Build it convenient to communicate with companies/organizations (SI6) } \\
\text { Rest assured that the product ordered will be sent as promised (SI7) }\end{array}$ \\
\hline
\end{tabular}

The research model in SEM analysis is an explanatory research according to the level of explanation. The level of explanation aims to explain the position of the variables under study and the relationship between one variable and another. The research variables used in this study are:

a. Web service quality is what is referred to as service quality is the difference between the expectations and the reality of the customer for the service received. The dimension used includes usability, quality of information, and service interactions with 22 indicators above.

b. Satisfaction is the difference between expectations and the performance or results felt by customers. Satisfaction indicators include product quality, service quality, emotional, price, cost, and convenience.

c. Loyalty is a firmly held commitment to repurchasing or repeating a preferred product/service consistently in the future, thus leading to the purchase of the same brand, despite situational influences and marketing efforts that could potentially lead to a shift in behavior. Loyalty is measured by three indicators, including recommending the Shopee website, making repeated purchases, and future transactions.

All variables in this study are latent or construct variables, namely variables that cannot be measured directly (unobserved). Therefore, the existence of these latent variables is measured by statement indicators in Likert scale. In this study, the measurement of the statement used a five-level Likert scale, namely: 1: Strongly Disagree, 2: Disagree, 3: Neutral, 4: Agree, 5: Strongly Agree.

\subsection{Data analysis}

Following are the data analysis steps of this research:

\section{Step 1: Validity and reliability test}

According to Sekaran in Jusoh, et al. [26], better instruments will better guarantee the accuracy of the results, which will improve the scientific quality of the research. Therefore, it is necessary to assess how good the measurements (goodness of measurement) in this study. To measure the goodness of measurement, this study used the validity test and reliability test.

\section{Step 2: WebQual with Importance Performance Analysis (IPA)}

WebQual is one of the most widely used techniques for quantifying a website's quality based on user or visitor perceptions. The development of WebQual started with WebQual 1.0 and finally became WebQual 4.0 with the latest dimensions are usability, information quality, and service interaction. The Importance Performance Analysis (IPA) method aims to quantify the connection between consumer 
perceptions and product/service quality improvement priorities, known as quadrant analysis [27]. IPA combines the metering of the stage of importance (expectation) and the stage of performance (perception) in a two-dimensional graph that makes it simple to decipher the data and to get practical tips [14]. The IPA graph is divided into four quadrants.

\section{Step 3: SEM analysis}

SEM analysis is used for processing techniques and data analysis which is a multivariate statistical method with a combination of two analyzes, namely factor analysis and regression analysis (correlation). SEM analysis has the objective of checking and verifying the relationship between the variables of the model, either between indicators and constructs or relationships between constructs [28]. SEM used in this study is covariance-based SEM (CB-SEM or Covarians Based-Structural Equation Modelling), which intercorrelates or frees the indicators to correlate with the indicators and their latent variables. The data processing process in this study used statistical programs/software Amos and SPSS. The hypothesis resulting from the SEM analysis is:

a. Service quality has a significant positive impact on consumer loyalty to Shopee.

b. Customer satisfaction has a significant positive impact on customer loyalty at Shopee.

c. Service quality has a significant positive impact on customer satisfaction at Shopee.

\section{Step 4: Integration of WebQual with Importance Performance Analysis (IPA) and SEM analysis}

The final analysis step is carried out to select the similarity of the attributes that appear in the WebQual analysis with IPA and the WebQual attributes that form the fit model from the results of the confirmatory analysis in the SEM analysis. This attribute will be the basis for e-commerce management considerations to achieve customer satisfaction and loyalty.

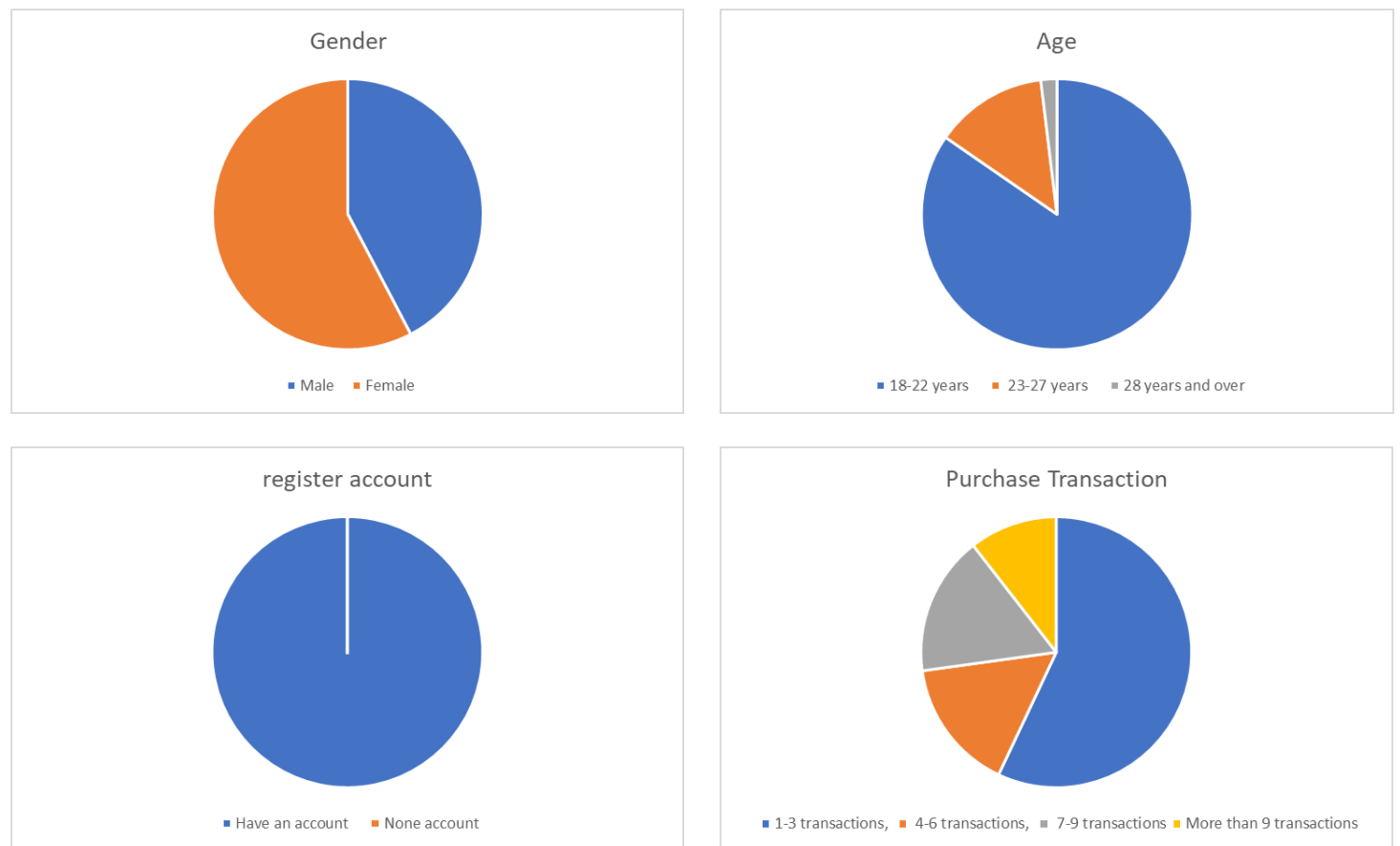

\section{Results and Discussion}

Fig. 3. Demographics of respondent

\subsection{Demographics of respondents}

The number of questionnaires collected was 115, following the election outcomes, a total of 104 respondents were used in this research. The limited number of respondents was caused by limited research time and the COVID-19 pandemic, limiting the space for distributing questionnaires. Questionnaires were distributed through the e-questionnaire using Google Form. Respondent's demographic is divided into gender, age, user registration date, transactions at Shopee, and the number of purchases of goods on Shopee e-commerce. For gender, the results obtained that as many as 44 respondents are male and 60 respondents are female. Second, for the age category of respondents, the results of respondents fall in the age range of 18-22 years old are 88 respondents, the age range of 23-27 years old are 14 respondents, and the age range 28 years and over are 2 respondents. Third, for account 
registration and transactions, the results show that all respondents have accounts at Shopee and have had transactions at Shopee. Fourth and for the latter, the category of the number of purchase transactions in a period of 6 months, the results of the data obtained are that 65 respondents had 1-3 transactions, 18 respondents had 4-6 transactions, 19 respondents had 7-9 transactions, and 12 respondents had more than 9 transactions. The demographic of the respondents can be found in Fig. 3 .

\subsection{Validity and reliability test}

A validity test is required to find the level of reliability of quantifying equipment used in testing. The validity test is carried out by appeal the calculated r-value (Pearson Correlation) with the $r$ table, which has a significant of 5\% [29]. Validity test results of the performance level and importance of each question variable is shown in Table 2 and Tables 3, and the results of the Corrected Item-Total Correlation value is computed using SPSS. The data is valid if the value of $r$ count $>0.1909$.

Table 2. Results of the validity level of performance

\begin{tabular}{llll}
\hline \multicolumn{1}{c}{ Category } & Indicator & Pearson Correlation & Validity \\
\hline Usability & US1 & $.809^{* *}$ & Valid \\
& US2 & $.841^{* *}$ & Valid \\
US3 & $.827^{* *}$ & Valid \\
US4 & $.801^{* *}$ & Valid \\
& US5 & $.771^{* *}$ & Valid \\
& US6 & $.691^{* *}$ & Valid \\
& US7 & $.779^{* *}$ & Valid \\
Information Quality & US8 & $.721^{* *}$ & Valid \\
& IQ1 & $.889^{* *}$ & Valid \\
& IQ2 & $.856^{* *}$ & Valid \\
& IQ3 & $.804^{* *}$ & Valid \\
& IQ4 & $.900^{* *}$ & Valid \\
& IQ5 & $.839^{* *}$ & Valid \\
& IQ6 & $.787^{* *}$ & Valid \\
Service Interaction Quality & IQ7 & $.884^{* *}$ & Valid \\
& SI1 & $.825^{* *}$ & Valid \\
& SI2 & $.830^{* *}$ & Valid \\
& SI3 & $.889^{* *}$ & Valid \\
& SI4 & $.785^{* *}$ & Valid \\
SI5 & $.857^{* *}$ & Valid \\
SI6 & $.812^{* *}$ & Valid \\
SI7 & $.740^{* *}$ & Valid \\
\hline
\end{tabular}

The reliability check is utilized to specify the stage of consistency of respondents in replying inquiries [30]. Cronbach's Alpha value shows reliability test with the provision that the value limit is > 0.7 [31]. Calculation of Cronbach's Alpha level of work and level of importance in this study can be found in Table 4.

\subsection{Gap analysis (GAP)}

The analysis was carried out by calculating the average value of assessing user perceptions and expectations of website quality [32]. The result of the gap analysis is detailed in Table 5.

By looking at the measurement results in Table 5, it can be found that for each attribute of the three assessed WebQual dimensions, the importance score is greater than the performance score. Even if observed further, the gap between the importance score and the performance score has a negative value for each attribute and has an overall average value of -0.23 . It can be said that all attributes in the existing WebQual dimension have not met user expectations because the performance has not been the same or exceeded the importance score, so that it is negative. The expectations of the user are still much greater than what they feel. Parallel with the outcomes obtained by Christianto et al. [7], the average value of the difference in the gap of all attributes of the three dimensions used is -0.40 . It has not met the level of user expectations compared to the performance level of the website. Based on the research results from the gap analysis, the gap value obtained from all attributes is negative and the average value of the gap is -0.23 . It can be concluded that the e-commerce website has not met the level of expectations of its users compared to the given performance level. The three highest differences in the gap are obtained by the attributes of SI7, IQ2, and IQ3. In contrast to the research results obtained by 
Andry et al. [6] where the e-commerce website has met the level of user satisfaction even though it gets an average score of -0.41 .

Table 3. Results of the validity level of importance

\begin{tabular}{llll}
\hline Category & Indicator & Pearson Correlation & Validity \\
\hline Usability & US1 & $.827^{* *}$ & Valid \\
& US2 & $.835^{* *}$ & Valid \\
& US3 & $.879^{* *}$ & Valid \\
& US4 & $.804^{* *}$ & Valid \\
US5 & $.816^{* *}$ & Valid \\
& US6 & $.758^{* *}$ & Valid \\
US7 & $.828^{* *}$ & Valid \\
& US8 & $.782^{* *}$ & Valid \\
Information Quality & IQ1 & $.920^{* *}$ & Valid \\
& IQ2 & $.913^{* *}$ & Valid \\
& IQ3 & $.865^{* *}$ & Valid \\
& IQ4 & $.920^{* *}$ & Valid \\
& IQ5 & $.878^{* *}$ & Valid \\
& IQ6 & $.884^{* *}$ & Valid \\
IQ7 & $.873^{* *}$ & Valid \\
Service Interaction Quality & SI1 & $.869^{* *}$ & Valid \\
& SI2 & $.852^{* *}$ & Valid \\
& SI3 & $.912^{* *}$ & Valid \\
& SI4 & $.831^{* *}$ & Valid \\
& SI5 & $.910^{* *}$ & Valid \\
SI6 & $.887^{* *}$ & Valid \\
& SI7 & $.840^{* *}$ & Valid \\
\hline
\end{tabular}

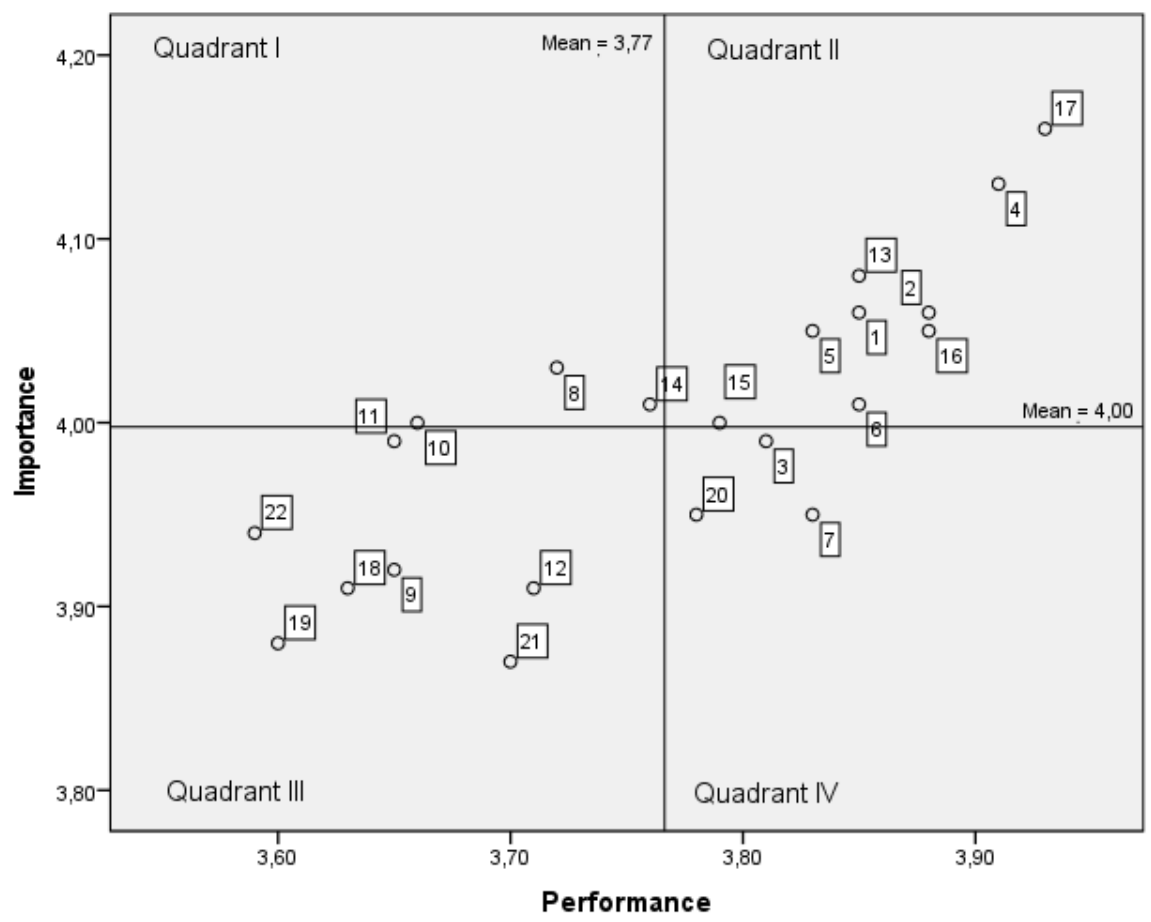

Fig. 4. Quadrant IPA

Table 4. Results of the reliability test

\begin{tabular}{lll}
\hline \multicolumn{1}{c}{ Instrument } & Cronbach's Alpha & Reliability \\
\hline Performance & 0.964 & Reliable \\
Importance & 0.975 & Reliable
\end{tabular}

From the results of this analysis, a managerial implication can be taken by e-commerce to improve the e-commerce website's performance in order to meet the satisfaction level of the Shopee's user. All attributes' overall performance must be improved, especially for the top three attributes with the highest gap value. By improving these attributes, the company's performance results will increase to face strict competition between emerging e-commerce giants in Indonesia and the enterprise purpose can be reached. 


\begin{tabular}{lllll}
\multicolumn{5}{c}{ Table 5. Gap Analysis } \\
\cline { 5 - 5 } No & \multirow{2}{*}{ Attribute } & $\begin{array}{l}\text { Mean } \\
\text { Imp. }\end{array}$ & Perf. & Gap \\
\hline 1 & US1 & 4.06 & 3.85 & -0.21 \\
2 & US2 & 4.06 & 3.88 & -0.18 \\
3 & US3 & 3.99 & 3.81 & -0.18 \\
4 & US4 & 4.13 & 3.91 & -0.21 \\
5 & US5 & 4.05 & 3.83 & -0.22 \\
6 & US6 & 4.01 & 3.85 & -0.16 \\
7 & US7 & 3.95 & 3.83 & -0.13 \\
8 & US8 & 4.03 & 3.72 & -0.31 \\
9 & IQ1 & 3.92 & 3.65 & -0.27 \\
10 & IQ2 & 4.00 & 3.66 & -0.34 \\
11 & IQ3 & 3.99 & 3.65 & -0.34 \\
12 & IQ4 & 3.91 & 3.71 & -0.20 \\
13 & IQ5 & 4.08 & 3.85 & -0.23 \\
14 & IQ6 & 4.01 & 3.76 & -0.25 \\
15 & IQ7 & 4.00 & 3.79 & -0.21 \\
16 & SI1 & 4.05 & 3.88 & -0.17 \\
17 & SI2 & 4.16 & 3.93 & -0.23 \\
18 & SI3 & 3.91 & 3.63 & -0.29 \\
19 & SI4 & 3.88 & 3.60 & -0.28 \\
20 & SI5 & 3.95 & 3.78 & -0.17 \\
21 & SI6 & 3.87 & 3.70 & -0.16 \\
22 & SI7 & 3.94 & 3.59 & -0.36 \\
\hline & \multirow{2}{*}{ Average } & 4.00 & 3.77 & $-\mathbf{0 . 2 3}$ \\
& & & & \\
\hline & &
\end{tabular}

\subsection{Importance Performance Analysis (IPA)}

Importance Performance Analysis (IPA) is recommended by the company to specify the level of customer satisfaction. Companies compare customer expectations with their performance. If the expectation level is greater than the the company's performance, it has not met satisfaction [33]. The output of the IPA analysis consists of indicators in the IPA matrix which are divided into four quadrants [34]. The quadrant of the test results using IPA is depicted in Fig. 4 and the result is detailed in the discussion section.

In Fig. 4, it can be inferred that all items have been mapped into four quadrants, namely:

a. Quadrant I shows that there are 3 attributes included in quadrant I, namely attributes with the code US8 (The website creates a positive/absolute experience), IQ2 (Provide reliable information), and IQ6 (Provide detailed information). For comparison, the results of the Quadrant I in Andry et al. [6] with the attributes: ease of operating the website (US1), design according to the type of website (US6), the website creates a positive experience (US8), provide timely information (IQ3), and provide detailed information (IQ6). The attributes with the same result are code US8 and IQ6.

b. Quadrant II shows that there are 9 attributes included in quadrant II, namely attributes with the code US1 (Ease of operating the website), US2 (Interaction with the website is easy to understand), US4 (Convenient of use of the website), US5 (The website has an interesting look), US6 (Type of website based on its design), IQ5 (Provide information which is simple to digest), IQ7 (Provide output/information according to format), SI1 (Have a good reputation), and SI2 (Feel protected and safe to carry out transactions). For comparison, Andry et al. [6] obtained the results in quadrant II with the attributes: interaction with the website is easy to understand (US2), the website has an attractive appearance (US5), have a good reputation (SI1), feel safe to complete transactions (SI2), can guarantee the safekeeping of personal information (SI4), make it easy to communicate with companies/organizations (SI6), and feel confident that the product ordered will be delivered as promised (SI7). The attributes with the same result are code US2, US5, SI1, and SI2.

c. Quadrant III represents the attributes that fall into the low priority category or doesn't need attention. Quadrant III shows that there are 7 attributes that are included in this quadrant, namely IQ1 (provide accurate information), IQ3 (provide timely information), IQ4 (provide relevant information), SI3 (Feel safe providing personal information), SI4 (can guarantee the maintenance 
of personal information), SI6 (Build it convenient to communicate with companies), and SI7 (Rest assured that the product ordered will be sent as promised). For comparison, Andry et al. [6] obtained the results in quadrant II with the attributes of ease of navigating the website (US3), website easy to use (US4), the website is convincing and competent (US7), supply accurate information (IQ1), supply reliable information (IQ2), supply relevant information (IQ4), provide information that is easy to understand (IQ5), and provide information according to format (IQ7). The attributes with the same result are code IQ1 and IQ4.

d. There are three attributes included in Quadrant IV, namely the US3 attribute (Ease of navigating the website), US7 (Website is convincing and competent), and SI5 (Have a good image in the community). The position of the attributes in Quadrant IV is an excessive condition, and these attributes have a poor level of importance but a higher level of performance so that they have excessive quality so that users are often ignored. For comparison, Andry et al. [6] obtained the results in Quadrant II with the attributes of feeling safe providing personal information (SI3) and have a good image in the community (SI5). The attribute with the same result is code SI5.

Table 6. Standardized Regression Weights \& Regression Weights

\begin{tabular}{lllll}
\hline & & & Estimate & C.R. \\
\hline Usability & $<---$ & Service_Quality & .820 & 5.657 \\
Information_Quality & $<---$ & Service_Quality & .930 & 7.052 \\
Service_Interaction & $<---$ & Service_Quality & .947 & \\
X1.8 & $<---$ & Usability & .683 & \\
X1.7 & $<---$ & Usability & .634 & 5.961 \\
X1.6 & $<--$ & Usability & .625 & 5.876 \\
X1.5 & $<--$ & Usability & .387 & 3.719 \\
X1.4 & $<---$ & Usability & .767 & 7.096 \\
X1.3 & $<---$ & Usability & .827 & 7.582 \\
X1.2 & $<---$ & Usability & .838 & 7.670 \\
X1.1 & $<---$ & Usability & .767 & 7.095 \\
X1.15 & $<---$ & Information_Quality & .856 & \\
X1.14 & $<--$ & Information_Quality & .869 & 11.861 \\
X1.13 & $<--$ & Information_Quality & .885 & 12.281 \\
X1.12 & $<---$ & Information_Quality & .877 & 12.052 \\
X1.11 & $<---$ & Information_Quality & .742 & 9.083 \\
X1.10 & $<---$ & Information_Quality & .849 & 11.348 \\
X1.9 & $<---$ & Information_Quality & .813 & 10.515 \\
X1.22 & $<---$ & Service_Interaction & .703 & \\
X1.21 & $<---$ & Service_Interaction & .767 & 7.391 \\
X1.20 & <ervice_Interaction & .739 & 7.125 \\
X1.19 & Service_Interaction & .777 & 7.482 \\
X1.18 & Service_Interaction & .820 & 7.883 \\
X1.17 & & .688 & 6.654 \\
X1.16 & & .773 & 7.449 \\
\hline
\end{tabular}

\subsection{Structural Equation Model (SEM)}

\subsubsection{Stage of the measurement model (Measurement Model) and Confirmatory Factor}

The first basic stage in the SEM analysis technique is the measurement model stage (Measurement Model). The measurement model is used to measure the dimensions that make up a factor. Because it is related to a factor, we confirm whether the indicator variables can make up a factor. In other words, confirmatory factor analysis reflects a measurement model in which the observed variables define the latent construct or variable. The critical ratio (C.R) value $\geq 1.96$ indicates that the indicator validly measures what should be measured in the presented model [35]. In the standardized model estimation state, the confirmatory factor analysis test is applied. The result of standardized regression weights after testing is shown in the AMOS output table, Table 6. This indicator cannot represent the construct if the estimated value or factor loading of the indicator has a significance level of $\leq 0.40$, which is carried out by processing the respondent's answer data into a model which is the initial structural model in the 
figure using the AMOS 21 program, then a Regression Weight table (Loading Factor), Measurement Model, and Standardized Regression Weights can be compiled as follows [36].

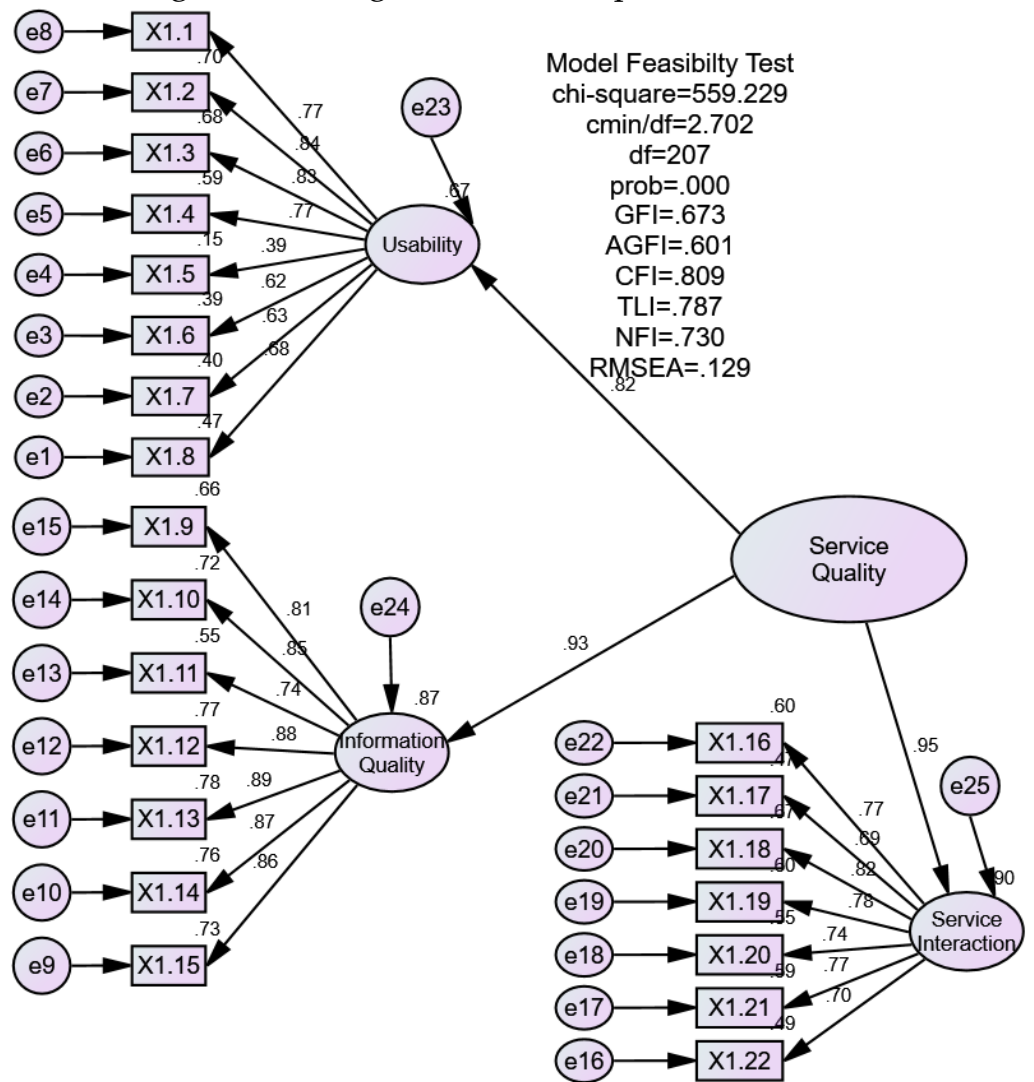

Fig. 5. Result of structural equation analysis in Model 1

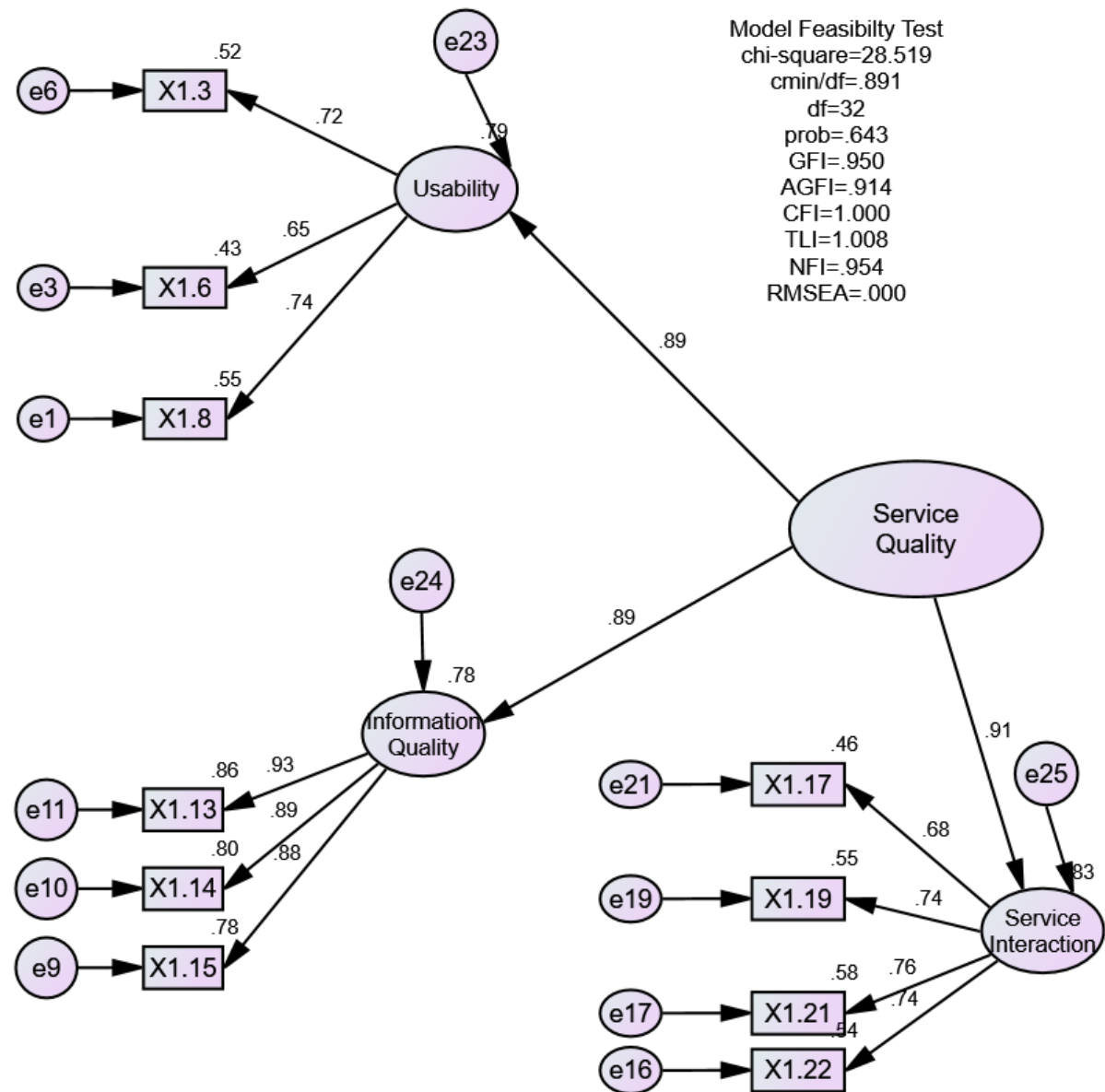

Fig. 6. Result of structural equation analysis in Model 2 
Table 6 implies that the Critical Ratio (C.R) value for all indicators has attended the required C.R value rule, which is the value of C.R $\geq 1.96$. It is concluded that the 22 indicators from model 1 have been able to quantify validly for the model presented in Fig. 5. In Table 6, it can be seen that almost all indicators have entered the requirements for an estimated value (loading factor) greater than 0.4 . So that a construct can be described. Although there is an indicator, namely X1.5, that has a value of $\leq 0.40$, namely 0.387 , this does not interfere with the research model.

Based on the outcome in Table 7, the outcome can be clarified that Model 1, the initial structural model of the research model, is not fit because it has an insufficient probability of 0,000 and does not meet several other criteria [35]. So that Model 1 needs to be modified. The result of the modified model is shown in Model 2.

Build upon the outcomes of Table 8, it can be concluded that Model 2, the modified initial structural model of the initial research model, is fit because it has a sufficient probability of 0.643 , and has met several other criteria [35]. From Fig. 6, this model proves the three dimensions that make up the quality of website services are usability, information quality, and service interaction with the remaining 10 indicators. Thus, the modification of the initial structural model can be used in the next stage. The next stage is to partially measure the customer satisfaction construct. Measuring the validity of the construct indicators for customer satisfaction can be checked in Table 9.

Table 7. Evaluation of goodness of fit criteria in Model 1

\begin{tabular}{lllc}
\hline Goodness of Fit Index & \multicolumn{1}{c}{ Cut-off Value } & Model 1 & Information \\
\hline $\mathrm{X}^{2}$ - Chi- Square & Smaller value is expected & 559.229 & $\mathrm{Bad}$ \\
Significance Probability & $\geq 0.050$ & 0.000 & $\mathrm{Bad}$ \\
CMIN/DF & $\leq 2.000$ & 2.702 & $\mathrm{Bad}$ \\
GFI & $\geq 0.900$ & 0.673 & $\mathrm{Bad}$ \\
AGFI & $\geq 0.900$ & 0.601 & $\mathrm{Bad}$ \\
TLI & $\geq 0.950$ & 0.787 & $\mathrm{Bad}$ \\
CFI & $\geq 0.950$ & 0.809 & $\mathrm{Bad}$ \\
RMSEA & $\leq 0.080$ & 0.129 & $\mathrm{Bad}$ \\
\hline
\end{tabular}

Table 8 Evaluation of goodness of fit criteria in Model 2

\begin{tabular}{cccc}
\hline Goodness of Fit Index & Cut-off Value & Model 2 & Information \\
\hline $\mathrm{X}^{2}$ - Chi-Square & Smaller value is expected & 28.519 & Good \\
Significance Probability & $\geq 0.050$ & 0.643 & Good \\
CMIN/DF & $\leq 2.000$ & 0.891 & Good \\
GFI & $\geq 0.900$ & 0.950 & Good \\
AGFI & $\geq 0.900$ & 0.914 & Good \\
TLI & $\geq 0.950$ & 1.008 & Good \\
CFI & $\geq 0.950$ & 1.000 & Good \\
RMSEA & $\leq 0.080$ & 0.000 & Good \\
\hline
\end{tabular}

Table 9 implies that the Critical Ratio (C.R) value for all indicators has passed the required C.R value rule, with the value of $C . R \geq 1.96$. It is concluded that the five indicators of the customer satisfaction have been able to validly quantify the model. In Table 9, it can be seen that all indicators have satisfied the requirements for an estimated value (loading factor) greater than 0.4 . So that a construct can be described. The next stage is to partially measure customer loyalty constructs. Measuring the validity of the construct indicators of customer loyalty can be checked in Table 10.

Table 9. Standardized regression weights

\begin{tabular}{lllll}
\hline & & Estimate & C.R. \\
\hline X2.1 <--- & Customer_Satisfaction & .775 & \\
X2.2 <--- & Customer_Satisfaction & .913 & 9.014 \\
X2.3 <--- & Customer_Satisfaction & .673 & 6.883 \\
X2.4 <--- & Customer_Satisfaction & .573 & 5.754 \\
X2.5 <--- & Customer_Satisfaction & .620 & 6.277 \\
\hline
\end{tabular}

Table 10 implies that the Critical Ratio (C.R) value for all indicators has passed the required C.R value rule, with the value of $C . R \geq 1$.96. It is concluded that the 3 indicators of the customer loyalty have been able to validly quantify the presented model. From Table 10, it can be seen that all indicators have satisfied the requirements for an estimated value (loading factor) greater than 0.4. So that a construct can be described. 


\begin{tabular}{llll}
\multicolumn{4}{c}{ Table 10. Standardized regression weights } \\
\hline \multicolumn{5}{c}{ Estimate } & C.R. \\
\hline X3.1 <--- & Customer_Loyalty & .630 \\
X3.2 <--- & Customer_Loyalty & .722 & 4.572 \\
X3.3 <--- & Customer_Loyalty & .703 & 4.597 \\
\hline
\end{tabular}

After measuring the indicators in each construct, the next step is to measure the validity of all indicators simultaneously. The result of measuring the validity of all indicators is shown in Table 11.

Table 11. Standardized Regression Weights \& Regression Weights

\begin{tabular}{lllll}
\hline & & \multicolumn{2}{l}{ Estimate } & C.R. \\
\hline X1.8 & $<---$ & Usability & .738 & \\
X1.6 <--- & Usability & .655 & 5.981 \\
X1.3 <--- & .720 & 6.522 \\
X1.15 <--- & Informability & .883 & \\
X1.14 <--- & Information_Quality & .893 & 13.043 \\
X1.13 <--- & Information_Quality & .925 & 13.946 \\
X1.22 <--- & Service_Interaction & .736 & \\
X1.21 <--- & Service_Interaction & .760 & 7.243 \\
X1.19 <--- & Service_Interaction & .742 & 7.076 \\
X1.17 <--- & Service_Interaction & .678 & 6.470 \\
X2.1 <--- & Customer_Satisfaction & .775 & \\
X2.2 <--- & Customer_Satisfaction & .913 & 9.014 \\
X2.3 <--- & Customer_Satisfaction & .673 & 6.883 \\
X2.4 <--- & Customer_Satisfaction & .573 & 5.754 \\
X2.5 <--- & Customer_Satisfaction & .620 & 6.277 \\
X3.1 <--- & Customer_Loyalty & .630 & \\
X3.2 <--- & Customer_Loyalty & .722 & 4.572 \\
X3.3 <--- & Customer_Loyalty & .703 & 4.597 \\
\hline
\end{tabular}

Table 11 implies that the Critical Ratio (C.R) value for all indicators has passed the required C.R value rule, namely the value of $C . R \geq 1.96$. It is concluded that the 18 indicators of the model have been able to validly quantify the presented model. The next stage in this study is to test the confirmatory factor analysis. The confirmatory factor analysis test is carried out on standardized estimated conditions. In Table 10, all indicators have passed the requirements for an estimated value (loading factor) greater than 0.4 . So that a construct can be described.

\subsubsection{Structural Equation Model (SEM) analysis stage}

\section{a. Overall model fit test results}

Because Confirmatory Factor Analysis analyzes the variables, it is apparent that each of these variables can be utilized to create latent constructs, so the next step is to analyze the model or latent contructs. Examination of the SEM model is carried out on the Goodness of Fit indices. One of the test instruments, the Chi-square, is very sensitive to sample size. The Chi-square score is a checking tool to quantify the whole fit. Chi-square checks the outcome and the score is considered good if the score is getting lower. The weakness of the Chi-square test requires to be overcome, one of which is by utilizing the Root Mean Square of Approximation (RMSEA) test tool that is relatively unaffected by the sample size. RMSEA is a close fit test, unlike Chi-square that is an appropriate test. The proper suitable test is less realistic compared to the close fit compatibility test because it is more realistic to quantify the application level of the model to the data. Apart from the RMSEA, the Goodness of Fit Index (GFI) and the Tucker Lewis Index (TLI) is also highly suggested because these indices are insensitive to the sample size and are less affected by the complexity of the model [35]. The results of the structural equation analysis in the model is illustrated in Fig. 7.

Based on the data in Fig. 7, it can be clarified that Model 3, which is the initial structural model of the research model, is not fit because it has an insufficient probability of 0.000 and does not meet several other criteria. So that Model 3 needs to be modified. In Fig. 8, the result of the model modification is shown in Model 4. 


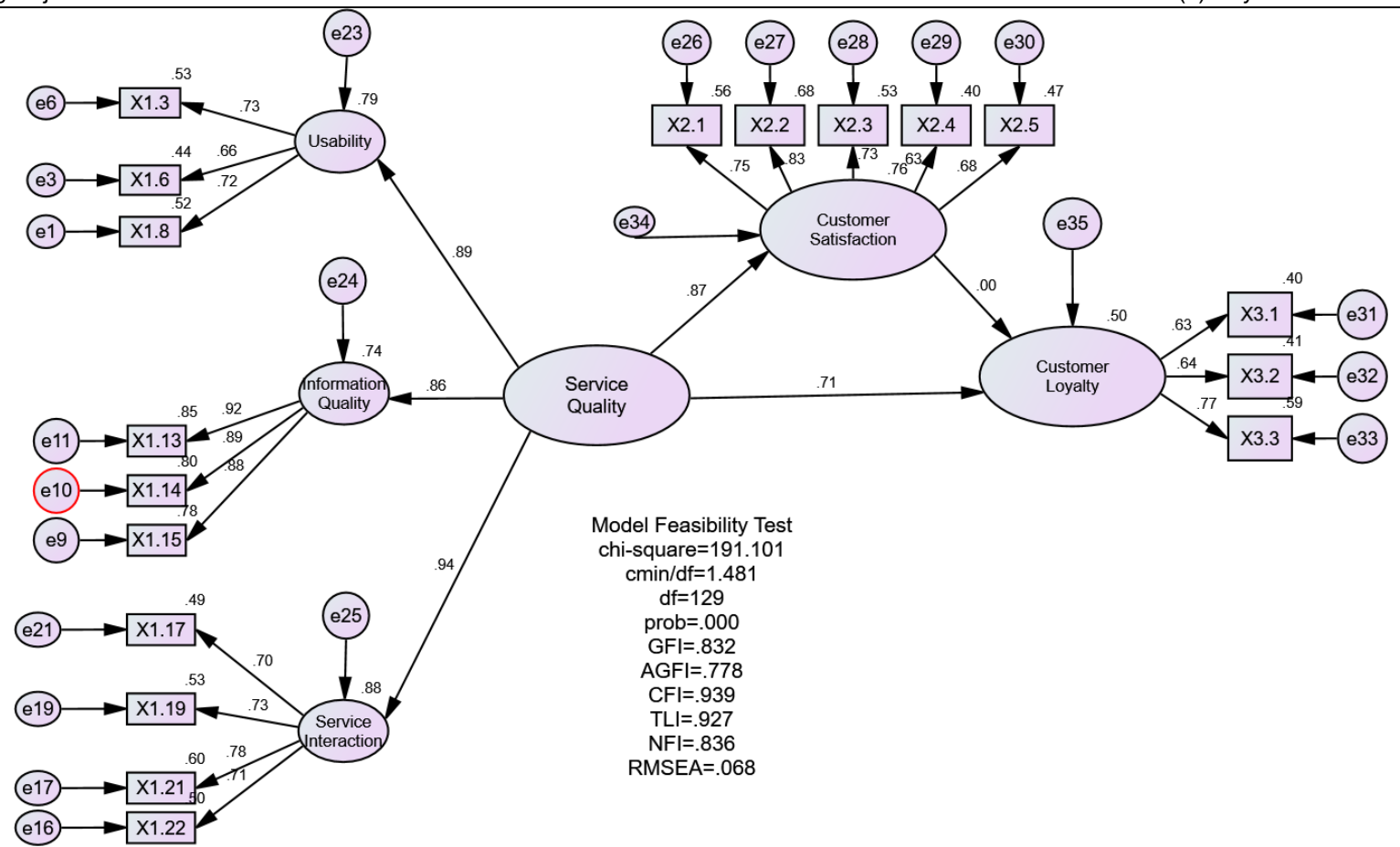

Fig. 7. Result of structural equation analysis in Model 3

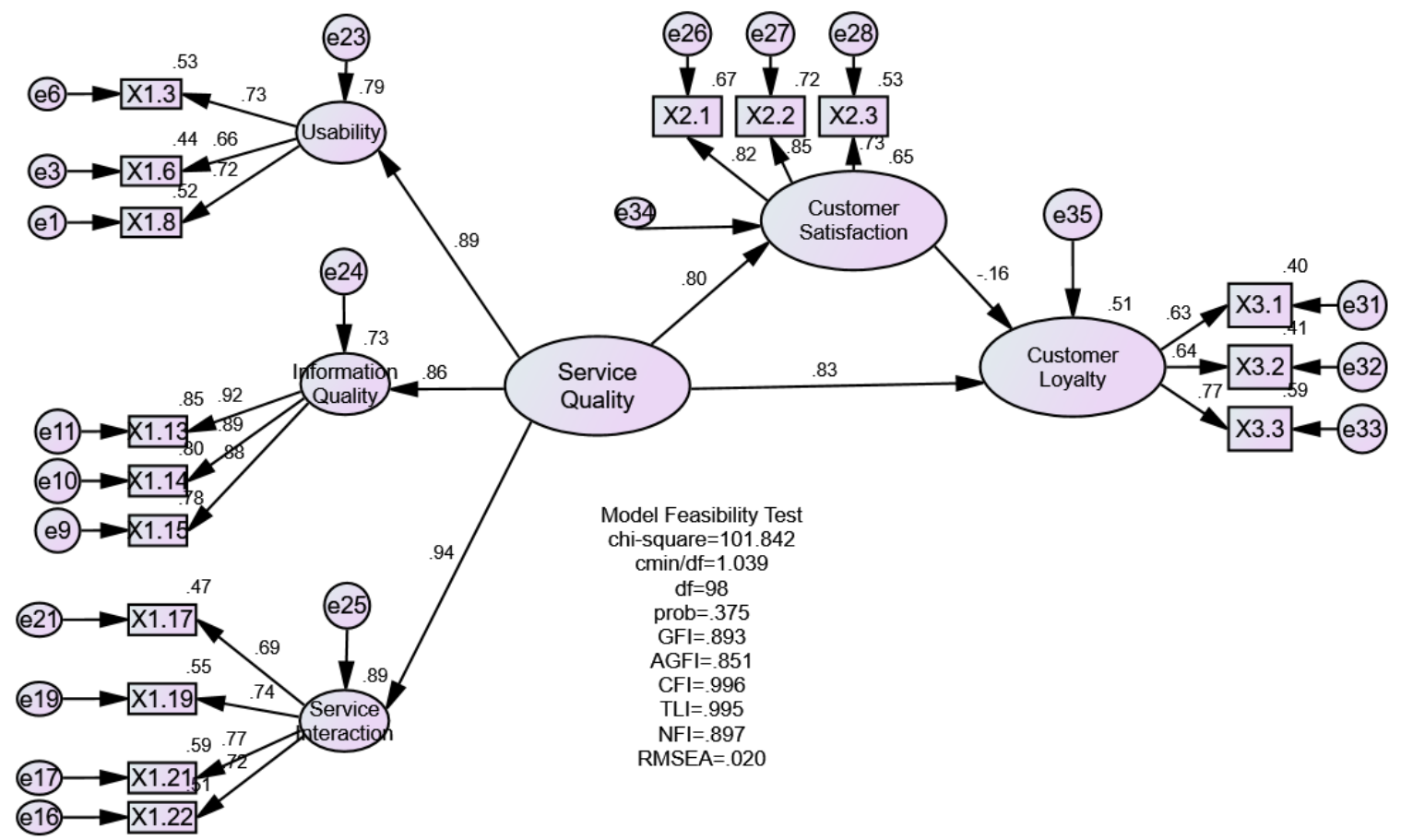

Fig. 8. Result of structural equation analysis in Model 4

Table 12. Evaluation of goodness of fit criteria in Model 2 (structural equations the effect of service quality and customer satisfaction in customer loyalty on e-commerce websites)

\begin{tabular}{llll}
\hline Goodness of Fit Index & Cut-off Value & Model 4 & Information \\
\hline$X^{2}$ - Chi-Square & Smaller worth is expected & 101.842 & Good \\
Significance Probability & $\geq 0.050$ & 0.375 & Good \\
CMIN/DF & $\leq 2.000$ & 1.039 & Good \\
GFI & $\geq 0.900$ & 0.893 & Marginal/Good \\
AGFI & $\geq 0.900$ & 0.851 & Marginal/Good \\
TLI & $\geq 0.950$ & 0.995 & Good \\
CFI & $\geq 0.950$ & 0.996 & Good \\
RMSEA & $\leq 0.080$ & 0.020 & Good \\
\hline
\end{tabular}


According to the data in Table 12, the Chi-square value originating from Model 4 is 101.842 while the probability is 0.375 is greater and better than Model 3. For the GFI and AGFI indices, the results for both indices in Model 4 have a value of less than 0,90 which are 0.893 and 0.851 . The GFI and AGFI values can be tolerated in the marginal category and this value is also better or the requirements have been met when compared to the index value of model 3. For the TLI and CFI indices, because the values of the two indices in Model 4 have values greater than 0.95, namely 0.995 and 0.996, it can be inferred that the requirements have been met [36]. From the CMIN/DF index generated in Model 4, it shows a value of $\leq 2.00$, namely 1.039. As well as for the RMSEA Index produced by Model 4 is less than 0.08 , which is 0.020 [37], so conclusions can be drawn that Model 4 in Fig.8 shows a fit result.

\section{b. Hypothesis test results (structural parameter estimates)}

The Structural Parameter Estimates test is performed to specify the relationship between the constructs or the independent and dependent variables in the structural model. Table 13 details the mensuration model with unstandardized and standardized weight.

Table 13. Regression weights

\begin{tabular}{|c|c|c|c|c|c|}
\hline & & Estimate & C.R. & $\mathbf{P}$ & Information \\
\hline Customer_Satisfaction & Service_Quality & .769 & 6.083 & *** & Significant \\
\hline Customer_Loyalty & $<--$ Customer_Satisfaction & -.137 & -.711 & .477 & Non-Significant \\
\hline Customer_Loyalty & Service_Quality & 685 & 3.149 & .002 & Significant \\
\hline
\end{tabular}

From Fig. 8 and Table 13, several conclusions can be drawn:

1). Between two variables, service quality and customer satisfaction, have a standardized regression weight coefficient value of 0.769 and C.R of 6.083 with a probability of 0.000 less than 0.05 or $p$ $<0.05$. From this outcome, it can be concluded that the variable service quality has a significant influence on the satisfaction variable on the e-commerce website The outcome of this research corresponds with the outcome yielded by Giao et al. [8], Zhou et al. [9], and Huang et al. [10].

2). Between two variables, customer satisfaction and loyalty, have a standardized regression weight coefficient value of -0.137 and C.R of -0.711 with a probability of 0.477 greater than 0.05 or $p>0.05$. From this outcome, it can be inferred that the variable customer satisfaction does not have a significant influence on the loyalty variable on the e-commerce website. The outcome of this research does not correspond with the outcome obtained by Giao et al. [8], Zhou et al. [9], and Huang et al. [10]. This result still needs to be discussed with further research.

3). Between two variables, namely service quality and loyalty, have a standardized regression weight coefficient value between 0.685 and C.R of 3.149 with a probability of 0.002 less than 0.05 or $p<0.05$. From this outcome, it can be concluded that the variable service quality has a significant influence on the loyalty on the e-commerce website. The outcome of this research corresponds with the outcome yielded by Giao et al. [8], Zhou et al. [9], and Huang et al [10].

\subsection{Integration of website service quality evaluation results with factors affecting e-commerce website customer loyalty}

Based on the study on the factors that impact the customer loyalty of the electronic commerce website with the SEM method, the results are that the variable website service quality has a significant impact on the variable of customer satisfaction on the e-commerce website, the variable customer satisfaction does not have a significant influence on the website customer loyalty variable. E-commerce web service quality variable has a significant effect on the customer loyalty variable on the e-commerce website to form a fit model. These three variables is formed by the three dimensions that form the web service quality variable, namely usability with indicators: "I found it simple to drive the website", "design according to the type of website", and "The website makes a positive/absolute experience". Second, the information quality dimension with indicators of "providing simple-to-understand information", "providing detailed information", "providing information following the format". Third, the dimension of service interaction with indicators in the form of "feeling safe in completing transactions", "ensuring the safeguarding of personal information", "making it easier to communicate with companies/organizations", and "feeling confident that the product ordered will be delivered as promised". From 22 indicators used in the WebQual 4.0 method to evaluate the website quality services, only 10 indicators form a fit model according to the result of the SEM analysis. 
The combination of the two analysis results with SEM is shown in Fig. 8 with the fit Model 4 and the WebQual method with IPA is shown in Fig. 4. We can analyze the same attributes from the two images. Indicators or attributes that need to be considered by the management of the e-commerce web management are divided into two parts, namely:

1). Consistency of Performance. The indicators are "design by the type of website" (Usability), "provide simple-to-understand information" (Information Quality), "provide information following the format" (Information Quality), and "feel safe to complete transactions" (Service Interaction). The performance of these indicators must be preserved to support the quality of ecommerce's website services, to increase the level of user satisfaction and customer loyalty.

2). Performance Improvement. The indicator is "the website makes the positive experience for me" (Usability), and "supplies detailed output or information" (Information Quality). These indicators have been considered important by customers. However, their performance must be improved to support the quality of e-commerce so that the level of customer satisfaction and customer loyalty can be achieved.

\section{Conclusion}

The resut of WebQual 4.0 with IPA shows that all attributes in the existing WebQual dimension have not met user expectations because the performance is not the same or exceeds the importance. It is negative and has an overall average value of -0.23 . The expectations of users are still far greater than what they feel, so that users have not felt satisfied with the performance of the e-commerce website. Some of the attributes of WebQual 4.0 need to be improved and maintained. From the results of the SEM hypothesis test, the result shows that service quality variables significantly influence e-commerce customer satisfaction variable with a probability of 0.000 less than 0.05 or $p<0.05$, customer satisfaction variable have no significant impact on e-commerce customer loyalty variable with a probability of 0.477 greater than 0.05 or $\mathrm{p}>0.05$ and website service quality variable significantly influence e-commerce website customer loyalty variable with a probability of 0.000 , less than 0.05 or $p<0.05$. Indicators that need to be considered by e-commerce management are divided into two parts, namely consistency of performance (performance must be maintained to increase the level of user satisfaction and customer loyalty) and performance improvement (performance must be improved to support the quality of the e-commerce so that the level of customer satisfaction and customer loyalty is achieved). For consistency of performance, the indicators are designed by the type of website (Usability), provide simple-tounderstand information (Information Quality), provide information following the format (Information Quality), and feel safe to complete transactions (Service Interaction). For performance improvement, the indicator is the website makes a positive experience (Usability) and supplies with detailed output/information (Information Quality). For further research, use other research methods to compare the results. The research limitation is that it only uses a sample from a tiny population.

\section{Author Contributions}

I Gusti Ngurah Satria Wijaya: Conceptualization and Formal Analysis. Evi Triandini: Formal Analysis and Review \& Editing. Ezra Tifanie Gabriela Kabnani: Resources. Syamsul Arifin: Formal Analysis.

\section{Acknowledgment}

Acknowledgments are addressed to all participants, namely ITB STIKOM Bali for students of Information Systems Research and Information Systems ITB STIKOM Bali who are the subject of the study. The same speech is also addressed to aim at research and community development institutes of ITB STIKOM Bali which supports funding in internal research with a decree number No. 229/LPPM/WRI/ITBSTIKOMBALI/WDS/VI/20.

\section{Declaration of Competing Interest}

We declare that we have no conflict of interest.

\section{References}

[1] M. Pradana, W. S, S. Syarifuddin and A. Putra, "Gap Analysis of Indonesian State-Owned Bank Internet Banking Website," in Proceedings of the International Conference on Industrial Engineering and Operations Management, Toronto, Canada, 2019. 
[2] A. Subiyakto, M. R. Juliansyah, M. C. Utami and A. Susanto, "Combining the Statistical and Interpretative Analyses for Testing E-Commerce Customer Loyalty Questionnaire," in 2018 6th International Conference on Cyber and IT Service Management (CITSM), Parapat, Indonesia, 2018.

[3] D. A. Mandira, "The Influence of Customer Trust, Service Quality, and Perceived Price on Customer Satisfaction and Customer Loyalty (Study on Customer of PT. Kobra Panca Sakti Expedition)," Universitas Jenderal Soedirman, Purwokerto, Indonesia, 2018.

[4] S. Liao, J.-C. Hong, M.-H. Wen, Y.-C. Pan and Y.-W. Wu, "Applying Technology Acceptance Model (TAM) to explore Users' Behavioral Intention to Adopt a Performance Assessment System for Ebook Production," EURASIA Journal of Mathematics, Science and Technology Education, vol. 14, no. 10, 2018.

[5] M. Jebraeily, B. Rahimi, Z. Z. Fazlollahi and H. L. Afshar, "Using SERVQUAL Model to Assess Hospital Information System Service Quality," Hormozgan Medical Journal, vol. 23, no. 1, 2019.

[6] J. F. Andry, K. Christianto and F. R. Wilujeng, "Using WebQual 4.0 and Importance Performance Analysis to Evaluate E-Commerce Website," Journal of Information Systems Engineering and Business Intelligence, vol. 5, no. 1, pp. 23-31, 2019.

[7] K. Christianto, D. Deny, C. Martino and D. Fischer, "Detikcom Website Analysis with WebQual 4.0 and Importance-Performance Analysis Method," International Journal of Open Information Technologies, vol. 8, no. 5, pp. 31-36, 2020.

[8] H. N. K. Giao, B. N. Vuong and T. N. Quan, "The influence of website quality on consumer's eloyalty through the mediating role of e-trust and e-satisfaction: An evidence from online shopping in Vietnam," Uncertain Supply Chain Management, vol. 8, p. 351-370, 2020.

[9] R. Zhou, X. Wang, Y. Shi, R. Zhang, L. Zhang and H. Guo, "Measuring e-service quality and its importance to customer satisfaction and loyalty: an empirical study in a telecom setting," Electronic Commerce Research, vol. 19, p. 477-499, 2019.

[10] P.-L. Huang, B. C. Lee and C.-C. Chen, "The influence of service quality on customer satisfaction and loyalty in B2B technology service industry," Total Quality Management \& Business Excellence, vol. 30, no. 13-14, pp. 1449-1465, 2019.

[11] S. A. Raza, A. Umer, M. A. Qureshi and A. S. Dahri, "Internet banking service quality, e-customer satisfaction and loyalty: the modified e-SERVQUAL model," The TQM Journal, vol. 32, no. 6, pp. 1443-1466, 2020.

[12] R. Mardatilla, "Pengaruh Kualitas Layanan Terhadap Kepuasan, Kepercayaan dan Loyalitas Pelanggan Pada E-Commerce (Studi Kasus: Berrybenka)," Universitas Brawijaya, Malang, Indonesia, 2017.

[13] H. Sørum, K. N. Andersen and R. Vatrapu, "Public websites and human-computer interaction: an empirical study of measurement of website quality and user satisfaction," Behaviour \& Information Technology, vol. 31, no. 7, pp. 697-706, 2012.

[14] M. L. Jundillah, J. E. Suseno and B. Surarso, "Evaluation of E-learning Websites Using the WebQual Method and Importance Performance Analysis," in E3S W eb of Conferences, 2019.

[15] F. H. Haryanti and R. Setyorini, "The Influence of Website Service Quality towards Consumer Satisfaction by Using WebQual 4.0 Method: Study on Grab Users in Bandung," Advances in Economics, Business and Management Research (AEBMR), vol. 92, pp. 326-333, 2019.

[16] R. A. Abumalloh, O. Ibrahim and M. Nilashi, "Loyalty of young female Arabic customers towards recommendation agents: A new model for B2C E-commerce," Technology in Society, vol. 61, 2020.

[17] W. Gata and O. G. H, "Analysis of Information System Quality of Service on BSI Academy's Environment Using WebQual Methods, Importance Performance Analysis and Fishbone," Journal of Theoretical and Applied Information Technology, vol. 95, no. 2, pp. 229-241, 2017.

[18] J. J. Kim, Y. Lee and H. Han, "Exploring competitive hotel selection attributes among guests: An importance-performance analysis," Journal of Travel \& Tourism Marketing, vol. 36, no. 9, pp. 9981011, 2019. 
[19] M. Susanty, T. W. Ningsih and M. F. Rissa, "Analysis of Customer Satisfaction with Importance Performance Analysis (IPA) Method in One of the Banking Industries," International Journal of Innovative Science and Research Technology, vol. 4, no. 7, pp. 421-425, 2019.

[20] P. Kotler and K. L. Keller, Marketing Management, Pearson, 2016.

[21] P. K. Karo, "Analysis of the Effects of Relational Marketing Towards Tourist Satisfaction Level On Organizing a Tourism Event In South Sumatra Province," Advances in Economics, Business and Management Research, vol. 111, pp. 90-98, 2019.

[22] P. Kotler and G. Armstrong, Principles of Marketing, Pearson, 2016.

[23] D. Desai, "An Empirical Study of Website Personalization Effect on Users Intention to Revisit Ecommerce Website Through Cognitive and Hedonic Experience," in Data Management, Analytics and Innovation, Singapore, 2019.

[24] A. Gandhy and J. A. Hairuddin, "Analysis of Promotion and Product Differentiation of Jukajo on Consumer Purchase Decision," Binus Business Review, vol. 9, no. 1, pp. 9-18, 2018.

[25] K. Annaraud and K. Berezina, "Predicting satisfaction and intentions to use online food delivery: What really makes a difference?," Journal of Foodservice Business Research, vol. 23, no. 4, pp. 305-323, 2020.

[26] M. S. Jusoh, M. H. Din, D. Hazliza and T. Suriani, "Construct Validity for Measuring Entrepreneurial Readiness Among Malaysian Higher Education Students: A Stochastic Measurement Model Approach," in MATEC Web of Conferences, 2018.

[27] J.-W. Bi, Y. Liu, Z.-P. Fan and J. Zhang, "Wisdom of crowds: Conducting importance-performance analysis (IPA) through online reviews," Tourism Management, vol. 70, pp. 460-478, 2019.

[28] J. F. Hair, J. J. Risher, M. Sarstedt and C. M. Ringle, "When to use and how to report the results of PLS-SEM," European Business Review, vol. 31, no. 1, pp. 2-24, 2019.

[29] A. Adelin and M. Silviana, "Website Services Quality Analysis of PT. Semen Baturaja (Persero) Tbk Toward User Satisfaction by Using WebQual 4.0 Method," Journal of Physics: Conference Series, vol. 1361, 2019.

[30] K. Škařupová, N. Singleton, J. Matias and V. Mravčík, "Surveying drug consumption: Assessing reliability and validity of the European Web Survey on Drugs questionnaire," International Journal of Drug Policy, vol. 73, pp. 228-234, 2019.

[31] K. S. Taber, "The Use of Cronbach's Alpha When Developing and Reporting Research Instruments in Science Education," Res Sci Educ, vol. 48, pp. 1273-1296, 2018.

[32] N. A. Hidayah, A. Subiyakto and F. Setyaningsih, "Combining WebQual and Importance Performance Analysis for Assessing A Government Website," in 2019 7th International Conference on Cyber and IT Service Management (CITSM), Jakarta, Indonesia, 2019.

[33] H. Tannady, F. Nurprihatin and H. Hartono, "Service Quality Analysis of Two of the Largest Retail Chains with Minimart Concept in Indonesia," Business: Theory and Practice, vol. 19, 2018.

[34] S. Sumiadji, F. Handoyo and F. Setiati, "Servive Quality on Education Institution: Satisfaction Index and IPA (Case Study on Accounting Department of State Polytechnic of Malang)," International Journal of Social Science and Business, vol. 3, no. 4, pp. 549-556, 2019.

[35] R. Sukwadi, H. Wee and C. Yang, "Supply Chain Performance Based on the Lean-Agile Operations and Supplier-Firm Partnership: An Empirical Study on the Garment Industry in Indonesia," Journal of Small Business Management, vol. 51, no. 2, pp. 297-311, 2013.

[36] A. J. Badgaiyan and A. Verma, "Does urge to buy impulsively differ from impulsive buying behaviour? Assessing the impact of situational factors," Journal of Retailing and Consumer Services, vol. 22, pp. 145-157, 2015.

[37] D. D. Isiyaku, M. A. F. Ayub and S. A. Kadir, "Antecedents to teachers' perceptions of the usefulness of ICTs for business education classroom instructions in Nigerian tertiary institutions," Asia Pacific Education Review, vol. 19, p. 337-352, 2018. 